\title{
Effect of Iron Deficiency Anemia on Intellectual Performance of Primary School Children in Islamabad, Pakistan
}

\author{
Kashif Iqbal ${ }^{1 *}$, Tasneem Zafar ${ }^{2}$, Zafar Iqbal $^{3}$, Mohammad Usman $^{4}$, Hafsa Bibi ${ }^{5}$, \\ Maria Sadaf Afreen ${ }^{5}$ and Javeid Iqbal ${ }^{1}$ \\ ${ }^{1}$ Faculty of Pharmacy, University of Balochistan, Quetta, ${ }^{2}$ Yusra Medical and Dental College, Islamabad, ${ }^{3}$ Mohi-Ud-Din Islamic \\ Medical College, Mirpur, AJ\&K, ${ }^{4}$ Abasyn University, Peshawar, ${ }^{5}$ Gomal University, Dera Ismail Khan, KPK, Pakistan \\ *For correspondence: Email: Kashifiqbal321@gmail.com; Tel: (+92) 966-730410. 333-9959480, 3356951284
}

\begin{abstract}
Purpose: To assess the differences, if any, in the intellectual performance scores of children who have iron deficiency anemia and those who are neither anemic nor iron-deficient in New Kashmir Model School, Islamabad, Pakistan.

Methods: A total of 108 primary New Kashmir Model School children of Islamabad, Pakistan between the ages of 7 to 9 years were included in the study. They were divided into two groups based on Iron deficiency anemia and Non-anemia children's. A brief clinical history and physical examination was performed. All the 5 mandatory subjects of WISC-R were administered to the children of both groups. Electronic cell counter was used for the evaluation of hemoglobin, packed cell volume (PVC), mean cell volume (MCV), Mean cell hemoglobin $(\mathrm{MCH})$ while serum parameters were determined after first separating serum from blood. Giemsa stain was used to evaluate red cell morphology.

Results: Seventy six of these children had iron deficiency anemia based on their hemoglobin, packed cell volume, serum iron, total iron binding capacity and serum ferritin levels. The remaining 32 children were neither anemic nor iron-deficient based on their profiles. Intellectual performance scores which comprised of central nervous system (CNS) impact, as well as hemoglobin, packed cell volume, serum iron, total iron binding capacity and serum ferritin levels and also clinical parameters for the iron deficiency anemia group, were significantly lower than those of the non-anemia group.

Conclusion: Iron deficiency anemia appears to be associated with lower intellectual performance scores in school children. These results support previous findings that iron depletion leads to psychological and developmental effects in children.
\end{abstract}

Keywords: Intellectual performance, Anemia, Children, Psychological and developmental effects

Tropical Journal of Pharmaceutical Research is indexed by Science Citation Index (SciSearch), Scopus, International Pharmaceutical Abstract, Chemical Abstracts, Embase, Index Copernicus, EBSCO, African Index Medicus, JournalSeek, Journal Citation Reports/Science Edition, Directory of Open Access Journals (DOAJ), African Journal Online, Bioline International, Open-J-Gate and Pharmacy Abstracts

\section{INTRODUCTION}

In a world plagued by poverty, ignorance, malnutrition and disease, Iron Deficiency Anemia (IDA) is a prominent and at times troublesome feature of today's health scene and about one billion people around the world suffer from this anemia caused by a sustained insufficiency of iron [1].

Iron is a key modulator of normal bone marrow erythropoietin and erythropoesis is function of the bone marrow [2]. IDA is the major adverse effect of iron deficiency. The other liabilities of iron deficiency include its effect on intellectual 
performance, immunity, leukocyte function, physical work capacity, growth velocity, epithelial change, fertility, malignancy, neurological function and intelligence [3-8].

Iron deficiency has adverse effects on selective cognitive processes rather than on a global mental ability like intelligence. It is said to selectively affect only the non-verbal or performance scores while leaving the verbal intelligence scores unaffected [12]. Intelligence has been defined by Wechsler, as the overall capacity or ability of an individual to learn or understand and cope with the world around him and was used for this research [9-11].

Consent was taken from the school authority as well as parents. School authority permitted and parents agreed for given research on their children while written permission was also taken from ethical committee having official handover [20].

This school-based study was designed to assess the effect of IDA on the intellectual performance of school children. It was hoped that it would add to the extremely limited pool of knowledge on this subject, in Islamabad as well as in other areas of Pakistan.

\section{METHODS}

This study was carried out on 108 children of Islamabad. They were screened from various educational institutions and were aged between 7 to 9 years and thus, ensuring a minimum of 2 years full time primary school education. This was thought necessary to facilitate detection of subtle or significant differences in intellectual performance. Those children who had a recognizable, acute or chronic ailment were excluded from study.

The participating children were placed in 2 groups. Group I consisted of 76 children. They had iron deficiency anemia according to the criteria given in Table 2. Group II comprises of 32 students who were controlled (non-anemia).

The criteria for inclusion in this matched control group are also given in Table 2. The children were examined in the familiar surroundings of their primary schools. A brief clinical history and physical examination was performed.

All the 5 mandatory subjects of WISC-R [9] were administered to the children of both groups. Every effort was made to remove their apprehensions and to carry out the test in a relaxed atmosphere.

The children were motivated to successfully undertake the test. The directions, provisions and procedures of the test were strictly adhered too. This was considered necessary for the full appraisal of intellectual performance.

Finally a $5 \mathrm{ml}$ sample of venous blood was taken from each participating child. Electronic cell counter was used for the evaluation of hemoglobin, packed cell volume (PVC), mean cell volume (MCV), mean cell hemoglobin $(\mathrm{MCH})$ while serum parameters were determined by first separating serum from the blood. A drop of blood was placed on a glass slide and a smear was made. This was then stained by Giemsa stain and red cell morphology evaluated.

\section{Statistical analysis}

Data were expressed as mean \pm standard error for all parameters. Statistical software Minitab 15 was used to obtain $p$-values for the data. For the comparison of statistical significance between cases and control, Student t-test was used.

\section{RESULTS}

A total of 108 students were assessed 76 of them were in the IDA group I and the remaining 32 in the iron replete non-anemic or control.

Group II. The minimum age was 7 years while the maximum age was 9 years. Mean age was 8.1 years in group I and 8.2 years in group II. The clinical features of the participating students were recorded and are given in Table 3.

At the time of examination 56 students of group I were compared to only 5 students of group II showing signs and symptoms. Thus, a distinctly higher proportion of students from group I than those of group II showed clinical manifestation. Pallor, breathlessness on exertion, irritability, fatigue and decreased attention Span were the main complaints. Help in these observations was also obtained from the teachers.

Table 4 shows the results of the laboratory investigations. The hemoglobin levels of group I were lower than those of group II. Similarly, the $\mathrm{PCV}, \mathrm{MCV}, \mathrm{MCH}$ and $\mathrm{MCHC}$ values were lower in group I than group II. Serum iron and serum ferritin levels were less in group I but in group II, they were within the reference range. 
Table 1: Areas of possible CNS impact by iron deficiency

\begin{tabular}{|c|c|c|}
\hline $\begin{array}{l}\text { Biochemical } \\
\text { parameter }\end{array}$ & Specific site & Impact \\
\hline Haem Synthesis & $\begin{array}{l}\text { Porphyrinsynthesis } \\
\text { Mitochondrial cytochromes } \\
\text { Microsomal cytochromes }\end{array}$ & $\begin{array}{l}\text { Toxic or intracellular deficiency } \\
\text { respiratory oxidative } \\
\text { phosphorylation toxic }\end{array}$ \\
\hline Kreb's cycle & Succinate dehydrogenase & Respiration \\
\hline Fe-flavoprotein & $\begin{array}{l}\text { NADH-ubiqunon reductase alpha GP } \\
\text { dehydrogenase }\end{array}$ & $\begin{array}{l}\text { Respiration. Oxidative } \\
\text { phosphorylation }\end{array}$ \\
\hline Nucleic Acid & DNA synthesis, mitosis & Brain growth \\
\hline Catecholamine's & $\begin{array}{l}\text { Phenylamine hydroxylase, tyrosine hydroxylase, } \\
\text { Monoamine oxidase }\end{array}$ & Neurotransmitter levels \\
\hline Serotonin & $\begin{array}{l}\text { Tryptophan pyrolase, tryptophan hydroxylase, } \\
\text { aldehyde oxidase }\end{array}$ & Neurotransmitter levels \\
\hline Folic acid/B12 & Forminino transferase. THF methyl transferase & Brain function \\
\hline
\end{tabular}

Table 2: Grouping criteria

\begin{tabular}{lcc}
\hline Parameter & Iron-deficiency anemia (Group I) & $\begin{array}{c}\text { Non-anemia (control) } \\
\text { (Group II) }\end{array}$ \\
\hline Hemoglobin & $<$ II g/dl 1 & $<$ Il g/dl 1 \\
Packed cell volume & $<341 / 1$ & $>351 / 1$ \\
Serum iron & $<50 \mu \mathrm{g} / \mathrm{dl}$ & $<70 \mu \mathrm{g} / \mathrm{dl}$ \\
Total iron binding capacity & $>350 \mu \mathrm{g} / \mathrm{dl}$ & $<350 \mu \mathrm{g} / \mathrm{dl}$ \\
Serum ferritin & $<10 \mathrm{ng} / \mathrm{ml}$ & $>20 \mathrm{ng} / \mathrm{ml}$ \\
\hline
\end{tabular}

Table 3: Clinical presentation

\begin{tabular}{lcc}
\hline Manifestation & Group I (\%) & Group II (\%) \\
\hline Pallor & 61 & Nil \\
Shortness of breath & 21 & Nil \\
Decreased attention span & 20 & 09 \\
Irritability & 18 & 06 \\
Fatigue & 15 & 06 \\
Anorexia & 09 & Nil \\
Pica & 07 & 03 \\
Dizziness & 04 & Nil \\
Headache & 03 & Nil \\
\hline
\end{tabular}

Table 4: Laboratory investigation

\begin{tabular}{lcc}
\hline Parameter & Group I & Group II \\
\hline Hemoglobin $(\mathrm{g} / \mathrm{dl})$ & $9.7 \pm 0.82(8.3-10.9)$ & $13.22 \pm 1.1(12.1-14.8)$ \\
PVC $(1 / 1)$ & $32.05 \pm 2.76(26-34)$ & $38.7 \pm 2.8(35-45)$ \\
MCV $(\mathrm{fl})$ & $74.9 \pm 1.33(71-84)$ & $88.3 \pm 5.19 .02(79-95)$ \\
MCH $(\mathrm{pg})$ & $22.57 \pm 1.06(21-28)$ & $30 \pm 1.5(26-33)$ \\
MCHC $(\mathrm{g} / \mathrm{dl})$ & $29.1 \pm 0.99(26-31)$ & $32.97 \pm 1.18(30.8-35.4)$ \\
Serum Iron $(\mu \mathrm{g} / \mathrm{dl})$ & $39.6 \pm 8.8(23-49)$ & $97.86 \pm 18.2(71-140)$ \\
TIBC $(\mu \mathrm{g} / \mathrm{dl})$ & $408.8 \pm 42.9(326-521)$ & $294.8 \pm 24.4(223-342)$ \\
Serum ferritin $(\mathrm{ng} / \mathrm{ml})$ & $7.8 \pm 1.39(4.7-9.8)$ & $73.16 \pm 28.5(33-124.4)$ \\
\hline
\end{tabular}

Mean values with standard deviation; range is given in parenthesis

Table 5: Intellectual performance Test Scores

\begin{tabular}{lcc}
\hline Intellectual performance scores & Group I & Group II \\
(PS) & & $94.05 \pm 3.411$ \\
Mean Deviation & $87.07 \pm 2.571$ & $91-104$ \\
\hline
\end{tabular}

Probability value (Group I vs Group II): $p<0.001$ (statistically significant) 
However, TIBC in group I was higher than in group II. All these findings were consistent with the recognized protocols, as group I students has anemia and were iron deficient, while group II children were neither anemia nor iron deficient. The red blood cell morphology on peripheral blood smear showed hypothermia (66 \%), Microcytosis (45 \%) anisocytosis (16 \%), poikilocytosis $(8 \%)$ and target cells $(5 \%)$ in group I. While the morphology of group II was mostly normocytic normochronic (91\%), only 2 students showed microcytosis and hypochromia $(6 \%)$ and I showed macrocytosis (3\%). The scores obtained by the students of the two groups on intellectual performance/intelligence quotients (I.Q) tests (WISC-R) are given in Table 5. The intellectual performance (non-verbal (I.Q) scores of the iron deficiency anemia group I were lower than those obtained in the iron replace non-anemic (Control) group II. There was a significant difference in the values of scores between the two groups.

\section{DISCUSSION}

Iron represents a far living system. It is essential for oxidation reduction catalysis and bioenergetics, but unless appropriately shielded, it plays a key role in the formation of toxic oxygen radicals that can attack all biological molecules. Thus, on the one hand it is indispensable for life, while on the other hand, it has the potential to cause many deleterious impairment or oxidative destruction of the CNS components $[12,13]$.

In our study, the intellectual performance scores of the IDA students were lower than the scores of the iron non-anemic children. Thus, suggesting an association between IDA and intellectual performance, these results are similar to earlier findings by other workers who have also found impaired mental and motor function in children with iron deficiency [8].

Iron deficiency that has progressed to cause anemia will affect the tissues of iron and iron dependent enzymes in an uneven manner that cannot be fully predicted from the degree of an anemia. Many systems of the body including the CNS may be affected [5]

In the controversy on the effects of heredity and environment on intelligence, the effect of nutrition has either been ignored or has received a scant or oblique reference only. Numerous studies indicate that malnourished children perform significantly less on intellectual performance or cognitive tests. Thus, leading to the hypothesis that certain dietary inadequacies like iron have measurable psychological and developmental effects [15]

People in the developing countries are faced with health care crises. More than half of the population has already little or no access to health care services and many of them are forced to join the ranks of the deprived, while the quality of services, to those whom they are available, are getting poorer day by day. This shortage of access is most profound in the vital public health area like preventive health education. Iron deficiency is an important public health issue for children as it is the most common nutritional disorders of childhood.

We can say that anemia is caused by iron deficiency in whole of the world. Besides RBC's, Iron in the body is stored as ferritin or as hemosiderin and in macrophages, while one of the most important causes of iron deficiency anemia is gastrointestinal blood loss $[16,17]$.

\section{Limitations of the study}

Genetic study of IDA is required to understand the basics of disorder. However, improved understanding of the disorder will occur as more research is undertaken on the non-hematological liabilities of IDA. This study is an attempt in this direction. A better understanding of the effects of IDA on tissues may facilitate the development of sound strategies for the prevention and treatment of this disorder. Further, IDA is not the only etiological factor that determines the child's learning ability, although it may be a significant contributor. Hence, more work needs to be done to evaluate this and the tissues effects of IDA.

\section{CONCLUSION}

Iron deficiency anemia is still a major health care problem affecting millions of people all over the world, particularly pregnant women and children. IDA not only causes decreased physical and mental activity but also lowers intellectual performance. The findings of this study support earlier reports that iron deficiency anemia is associated with lower intellectual performance scores in school children.

\section{REFERENCES}

1. Anjum S, Rana IA, Sheikh MA. Effects of vitamin A supplements on iron status of anemic students. Pak J Biochem Mol Bio, 1998; 31: 1-5.

2. Ito $T$, Suzuki $A$, Imai $E$, Okabe $M$, Hori M. Bone marrow is a reservoir of repopulating mesangial cells during 
glomerular remodeling. J Am Soc Nephrol, 2001; 12: 2625-2635.

3. Weinberg ED. Iron therapy and cancer. Kidney Int. 1999; 55 (69): 131-134.

4. Penrod JC, Anderson K, Acosta PB. Impact on iron status of introducing cow's milk in the second six months of life. J Pediatr Gastroenterol Nutr, 1990; 10: 462-467.

5. Cazzola MJ, Bergamshi G, Dezza L, Arosio P. Manipulation of cellular iron metabolism for modulating normal and malignant cell proliferation: Achievements and prospects. Blood. 1990; 75 (10): 1903-1919.

6. Da Silva JL, Znad BA, Yang LM, Sabaawy HE, Lianos E, Abraham NG. Heme oxygenase isoform-specific expression and distribution in the rat kidney. Kidney Int. 2001; 59: 1448-1457.

7. Pollitt E. Effects of iron deficiency on mental development: Methodological considerations and substantial findings. In: Johnston FE, ed. Nutr Anthropol. New York: Liss; 1987; pp 225-254.

8. Corrigan $N$, Stewart $M$, Scott $M$, Fragile $X$. Iron and neurodevelopmental screening in eight year old children with mild to moderate learning difficulties. Arch Dis Child, 1997; 76: 264-267.
9. Wechsler D. Manual for the Wechsler Intelligence Scale for Children-Revised. New York: Psychological Corporation, 2nd edn, 1974.

10. Benton D. Vitamins and IQ. Br Med J, 1991; 302: 1021.

11. Schoenthaler S. Vitamins and IQ. Br Med J, 1991; 302: 1020-1021.

12. Ponka P. Cellular iron metabolism. Kidney Int, 1999; 55 : S2-S11; doi:10.1046/j.1523-1755.1999.055Suppl. 69002.x

13. Kuwabara $Y$, Sasaki $M$, Hirakata $H$, Koga H, Nakagawa M, Chen T, Kaneko K, Masuda K, Fujishima M. Cerebral blood flow and vasodilatory capacity in anemia secondary to chronic renal failure. Kidney Int, 2002; 61: 564-569.

14. Lawson MS, Thomson M, Hardiman A. Iron status of Asian children aged 2 years living in England. Arch Dis Child, 1998; 78: 420-426.

15. Andrews NC. Forgoing a field: the golden age of iron biology. Blood. 2008; 112 (2): 219-230.

16. Killip S, Bennett JM, Chambers MD. Iron deficiency anemia. Am Fam Physician. 2007; 75(5): 671-678.

17. International Ethical Guidelines for Biomedical Research Involving Human Subjects. Hinsdale (IL): CIOMS, Inc.; c2002 [cited 2013 Jan 5]. Available from http://www.cioms.ch/publications/layout_guide2002.p $d f$ 